\title{
Seventeenth-Century Funeral Sermons and Exemplary Female Devotion: Gendered Spaces and Histories
}

\author{
FEMKE MOLEKAMP
}

University of Warwick

Les sermons de funérailles $d u X V I I^{e}$ siècle, qui contiennent des eulogies pour des femmes décédées, peuvent être riches en détails et en constructions conceptuelles éclairant la vie dévotionnelle des femmes des débuts de la modernité. Cet article explore dans une sélection de ces eulogies les différentes représentations de l'espace spécifiquement féminin de la lecture, de la méditation et de la prière. On y examine également l'utilisation, dans ces sermons, de récits de lutte sur leur lit de mort contre Satan, afin de décrire une version féminine des dernières heures de la vie et de la lutte pour vaincre les tentations diaboliques. On y démontre que l'espace intime et le lit de mort féminins sont construits dans ces textes de telle sorte qu'ils y apparaissent comme des espace fonctionnant comme des frontières entre les espaces public et privé et entre la chasteté et la sexualité. Cet article souligne également la tension présente dans ces eulogies entre l'expression $d u$ pouvoir féminin d'action sur le plan religieux, et l'établissement de limites et de principes exemplaires de spiritualité féminine.

That closset of hers also at Truro, yea every place almost, would speak aloud of her constant reading, hearing, meditating on the Word, solemne Humiliations, solitary conferences with God, feruent prayers and eiaculations, which (as the sweetest incense) she euer and anon sent vp to the Throne of Grace. ${ }^{1}$

Drinted seventeenth-century funeral sermons commemorating women often 1 transmit a curious mixture of intimate detail and exemplarity in depicting the religious life of the deceased, even as the eulogies contained within these sermons reveal distinctive ways in which female devotional practice and its spaces were conceptualized. The minister Hannibal Gamon's tribute here to Lady Frances Roberts is typical in its representation of the interplay of the 
public and private, and of solemnity and immeasurable "feruent" pleasure, in domestic female devotional spaces. According to early modern terminology, "private devotion" signified devotional practice outside church, and might often involve a small group at home. "Solitary" devotion, sometimes termed "secret," is distinct from this, and is often associated with the personal religious passion of the "solitary" soul in conference with God. ${ }^{2}$ Seventeenth-century funeral sermons typically suggest that spaces for female devotion were used for both kinds of practice, while seeking to set limits and exemplary principles of conduct for these.

While commemorations of deceased men in early modern funeral sermons tended to laud public virtues, it was far more common for eulogies of women to index the personal piety and devotional conduct of the woman in the sphere of the home. These gendered differences are neatly demonstrated in a publication that places commemorations of a husband and wife side by side: The Wise and Faithful Steward. Or, a Narration of the Exemplary Death of Mr Beniamin Rhodes... Together with some Remarkable Passages concerning Mrs Anne Rhodes his wife, who dying few houres after him, was buried together in the same grave with him (1657). While Benjamin Rhodes is shown to be a pious man, he is praised for his "skill in business," his public integrity and "fidelity," and "how honestly and uprightly he managed all affairs." There is a more intense scrutiny of the devotional life of Anne Rhodes at home, ranging over her devotional reading and writing, and dwelling on her skills in translating the psalms "and other Essayes of her Poetical genius, which she exercised in divine matters only."3 There is also a more extensive account of Anne's spiritual experiences on the deathbed than of those of her husband. The deathbed, like the closet, is frequently treated in these eulogies as a site in which female spirituality plays out in specifically gendered ways, as this essay will explore.

In their blend of biographical detail and exemplary purpose, funeral sermons are an important source to add to other modes of life writing, such as spiritual autobiographies and diaries, for the recovery of female religious reading practices. Part of the peculiar interest of funeral sermons as resources in constructing a history of reading and devotional practice actually lies in their modes of exemplarity, which are centred on an urgent concern with making the act of reading itself exemplary. Stephen Zwicker has described the humanist culture of "exemplary reading" as "the careful study of texts for patterns of virtue... and the exportation of models of conduct and expression." ${ }^{\prime 4}$ Funeral 
sermons for women embody the culture of "exemplary reading" in a double way. First, they construct the reading (deceased) woman they are commemorating as an exemplar. Second, they show the deceased during her life engaged in practices of reading for "patterns of virtue," implicitly calling the reader to approach the funeral sermon itself in the same way, in order to mirror the deceased's exemplary reading. These funeral sermons, therefore, highlight the centrality of reading to the devotional life of early modern women and offer devotional reading strategies to her in printed form.

Printed funeral sermons grew in popularity in the seventeenth century; between 100 and 200 had been printed by 1640, with only 20 known to have been printed in the Elizabethan era. ${ }^{5}$ Their output increased from then until the turn of the eighteenth century. Funeral sermons were usually printed singly, although in 1647 a collection of 47 funeral sermons by eminent preachers was printed, entitled Threnoikos: The House of Mourning, demonstrating the popular place of the funeral sermon in the seventeenth century as a guide to leading an exemplary life, preparing for death, meditating on the next life, and responding to the death of loved ones. ${ }^{6}$ Funeral sermons thus held an important place in the memento mori tradition, and equally in the literature of exemplary reading for women. A higher proportion of funeral sermons for women were reprinted than those for men, making these interesting sources of conceptions of female piety. ${ }^{7}$

In tracing gendered histories and conceptions of reading, it is striking that funeral sermons for women are sometimes given titles that not only reference the gender of the deceased, but direct the sermon to a readership of the same gender. For example, William Compton's sermon on Mary Crosse is entitled $A$ lasting jewell for religious women (1630), and John Mayer's on Lucy Thornton, A patterne for women (1619). ${ }^{8}$ Funeral sermons for women were also often dedicated to women. The dedicatory epistle was often a place where the preacher connected the life and character of the living dedicatee with that of the deceased woman, praising the piety of two women (or more if there were multiple dedicatees) and drawing attention to the exemplary nature of the life described. The funeral sermon for Margaret Marwood (d. 1660), for instance, is dedicated to the sister of the deceased, Lady Wyvel. The author, George Ewbancke, describes the funeral, in the dedicatory epistle to Lady Wyvel, as a "manual" and professes that "as by my Pen I desire to do right to her that is dead, so by my prayers, I will endeavour that the reading of this may be of use to you that are 
alive, I pray let your Ladiships life be like hers." He continues: "O then get your soul (good madam) well stocked, well fortified, well furnished with a full stock of spiritual Ammunition and with the impenetrable Armorie of grace that may conduct you through all oppositions, to the Mansions of Glory where you shall meet with your friends that are dead in the Lord." A printed funeral sermon commemorating a woman was treated as a storehouse of spiritual ammunition, offering an exemplary portrait of the deceased. Its textual form transposed the original oration into something that could be intensively and repeatedly read. These sermons set themselves up as gateways to the "Mansions of Glory" to which pious women might ascend, providing exemplary devotional practices, and helps in time of spiritual struggle through observations of the pious life of the women they celebrated.

\section{Gendering devotional spaces}

The eulogies contained within funeral sermons for women often codify spaces for female reading, meditation, and prayer, focusing especially on the closet and the deathbed. They ubiquitously stress that the pious woman they celebrate spent daily time in "secret" devotion. The "secret" hours women spent with God took place in enclosed spaces, often the lady's personal closet. Margaret Marwood, for instance, is commemorated in her funeral sermon as "a constant closet-visitor, a constant worshipper, never forgetting nor omitting her hours of devotion." ${ }^{10}$ Sixteenth-century architecture saw "the creation of smaller and more private rooms in domestic structures of all types," and especially in country houses. ${ }^{11}$ Richard Rambuss stresses the increasing use of the closet at this time as a private Bible-reading space, where a reader may experience a more subjective, self-examining style of reading and "accrete the ever-receding declivities of a deepening, individuating awareness as the closet effects, the recessive architecture of the closet, the place of personal retreat within the house."12 It was, in fact, a place of readerly retreat particularly associated with women. ${ }^{13}$ Both the master and mistress of a noble early modern household might each be expected to have their own closet to retreat to, leading off their respective bedchambers. The female closet provided an intimate, solitary habitat for reading and devotion. It was not a straightforwardly private space, however, both because it participated in the larger architecture of the house, where husbands, 
servants, children, and visitors came and went, and because it served multiple purposes. Women's closets could be storehouses for domestic objects, and for making medicines, as well as housing devotional books and pious practice. ${ }^{14}$ Katherine Larson has explored the "liminal status" of the female closet, showing that it was both a private space for affective devotion and a conversational space at the threshold of various transactions. ${ }^{15} \mathrm{~A}$ funeral sermon for Elizabeth Thomason (d. 1659) uses a metaphor of conversation to depict Thomason's devotional practice inside the closet. We are told that Thomason "was a great lover of privacy and retirement, not at all given to idleness or tatling or wandring about from house to house, but very much conversant in her closet, reading and praying." 16 The choice of metaphor suggests a reluctance to conceive of women as truly alone in their closets, with unknowable thoughts and deeds. Rather, it is imagined that when she has retreated in her solitary devotion from societal observation and conversation, she is observed by God with whom she is in divine conversation.

Female devotion in the closet conforms to demands commonly made for female piety and chastity, which sought to circumscribe a narrow sequester for the early modern woman, keeping her to "privacy and retirement." In Richard Brathwaite's conduct manual The English Gentlewoman (1631) women are instructed to remember "we may be in security so long as we are sequestered from society." ${ }^{17}$ The funeral sermon for Katherine Brettergh draws on this ideal, as the author claims "she vsed not to gad abroad with wandring Dinah, to dancing greenes, markets, or publike assemblies; but rather with Hannah did chuse to tread vpon the dust of the sanctuarie." ${ }^{18}$ Brathwaite, in recommending seclusion to women, urges them: "Be you in your Chambers or Priuate Closets; be you retired from the eyes of men; thinke how the eyes of God are on you... [Be] still from the clamours and turbulent insults of the world; still from the mutinous motions and innouations of the flesh... You are taught to Enter your Chambers and be still. Still, and yet stirring still."19 Just as Elizabeth Thomason was depicted as closeted, yet "conversant," so Brathwaite attempts to negotiate a liminal state for closeted women, retired yet responsive; physically present and observed, yet without body, as all "mutinous motions and innouations of the flesh" are to be banished; "Still, and yet stirring still." This command reveals one of a number of binary oppositions that emerge in male constructions of this space. The closet was understood, for instance, to be both a chaste and a sexualized space. ${ }^{20}$ Alan Stewart has remarked on the "sexual anxiety about the female 
unlocked closet" in the early modern period, which emerges again from the identification of a woman's body with her room. ${ }^{21}$ Enclosure itself was felt to be both potentially protective of chastity, yet vulnerable to violation. Renaissance drama often stages illicit intrusion into a closet, as in Hamlet's forced entry to Ophelia's and then Gertrude's closet; or it dramatizes the closet as harbour of adultery, as in Arden of Faversham with Alice hiding from her husband with her lover in her closet; or in Marlowe's Massacre when Guise infiltrates his wife's closet to find her adulterous secrets.

Georgianna Ziegler has suggested that the early modern woman actually becomes identified with her room in the representation of her chastity, "from a long patriarchal tradition in which the chaste female is metaphorically an enclosed garden, vessel, or chamber," ordered to dwell in her confinement to remain chaste. ${ }^{22}$ Katherine Brettergh, who did not "gad abroad" to society, did instead daily practise "private prayer and meditation... both in her chamber, as also abroad secretly and solitarily in the orchard, garden, or fields." ${ }^{23}$ Private prayer and meditation itself becomes an enclosed female space like the lady's closet, or secreted places on her estate. As Brettergh was of a Puritan family, the emphasis on the multiplicity of private places where Brettergh might worship may also be taken as an expression of resistance to sacred spaces (churches) designated by conventional religion as necessary for devotional practice. There is still, however, a desire in the funeral sermon for the containment of Brettergh's prayer and meditation in "secret" spaces that are after all domestic, so far as they are on her estate. Gardens and galleries were sometimes associated with solitude, bordering the public and private spheres like the closet: potentially visible but harbouring recessed space in which it may be difficult to eavesdrop on conversation. As a woman, Brettergh may not "gad abroad" to read or pray, but neither need she be in a conventional sacred space.

A sermon preached at the funeral of Mary Blake (d. 1657) recalls that "shee was much in secret duties, in closet communion with God, and this did very much inrich her... when shee had once found the sweetnes of enjoying Christ behind the door... As secret meals makes a fat body, so shee found secret duties made a fat soul." ${ }^{4}$ Bearing in mind that these "secret duties" would have been textually based, or at least textually inspired, this metaphor of spiritual consumption yields an interesting representation of reading as incorporation, though of course the physical body has been transcended: it is the "soul" which grows "fat" with spiritual "meals." The role of female subjectivity, and the threat 
of the body, in private, affective devotion, is sometimes managed by recourse to the metaphor of mystical marriage, to represent feminine worship, as above in the suggestion that Blake had a habit of "enjoying Christ behind the door." The closet is not a place of spiritual solitude here, but a space in which a woman may be in conversation and "communion" with God. As husbands are left behind for private devotion, often practised in the closet, representations of both female devotion and the closet frequently yield the metaphor of mystical marriage, figuring the enclosed woman as Christ's Bride. ${ }^{25}$

Such representations, which carry a legacy from medieval affective piety, are drawn from conventional interpretations of the Song of Solomon. These are mediated particularly carefully in the sixteenth century by the Geneva Bible, which adds a headnote to this poetical book, stressing that "In this Song, Solomon by moste sweete and comfortable allegories and parables describeth the perfite love of Iesus Christ, the true Solomon and king of peace, and the faithful soul or his church, which he hathe sanctified and appointed to be his spouse, holy, chast, and without reprehension." ${ }^{26}$ The woman engaged in "secret" devotional reading and prayer, then, supposedly loses her corporeality but becomes simply the faithful soul, Christ's chaste spouse. Daniel Featley's popular devotion manual Ancilla Pietatis: or, the Handmaid to Private Devotion (1626) uses mystical marriage as an extended metaphor for the act of private devotion. Drawing on imagery from the Song of Solomon, Featley claims, "I haue brought thee into the Spouse garden of flowers \& spices; I haue gathered some out (almost) of euery bed, and layed by them a thred in the Analysis of Method, to binde them vp together. Make thou thy Posie as thy likest best; and breathe out with mee that sweete Prayer of the Spouse, cut in one of her knots." ${ }^{27}$ This association of mystical marriage with female devotion is a means of codifying the affective religious experiences of women, and of dispensing with the threats of the "mutinous" body.

As the authors of funeral sermons commemorating women make clear, the function of the female closet is defined by male expectations of female chastity and piety, and since the kind of prayer and meditation often practised in the closet would use (male-authored) devotional manuals containing set prayers, female devotion inside her little room could to some extent be controlled by the dominant (male) ideology. There persists nonetheless a possibility of female subjectivity provided by the closet which no one but the enclosed woman, the "reclusive self," can entirely grasp, despite Brathwaite's attempts to 
patrol and survey such a space. Frances Clifton, for instance, seemed to enjoy an authentically feminine subject position in endowing her closet or chamber with a unique, personal function one day each year, when, her funeral sermon tells us, she celebrated the anniversary of surviving a particularly difficult childbirth by devising a day "in her priuate Chamber with fasting, reading, Psalmes and prayer." ${ }^{28}$ Clifton's way of spending this anniversary each year can be seen symbolically as a version of gendered time as well as space.

It emerges in funeral sermons that the "secret" spaces for devotional reading and practice were not used exclusively by individuals, but were frequently inhabited by communities of women too, reading together in domestic spaces. These details of communal female religious reading accord with evidence in spiritual autobiographies and diaries that Protestant groups of women often read, prayed, and sang psalms together, and circulated books among themselves. ${ }^{29}$ The extensive account of Mary Gunter's conversion from Catholicism, contained in the printed funeral sermon for her, brings out the intersection of private and communal reading practices among women. The sermon heavily stresses the spiritual supervision and community, provided by Mary's older kinswoman and household mistress, Lady Lettice Dudley, during the conversion:

her Lady tooke from her all her Popish Bookes and Beads, Images, and all such trumpery, and set a narrow watch over her, that she might be kept from her Popish Prayers, and not absent her selfe from the daily prayers of the Familie, which were religiously observed: further, requiring her to reade those Prayers that her Honor daily vsed to haue in her private chamber with her women. ${ }^{30}$

The religious community of female devotion is offset here by its seclusion and privacy. As we have seen, private female devotion often took place in a woman's closet and was figured as "secret." Comparably, these prayers of a group of women take place in the intimate setting of Lady Dudley's "private chamber." Indeed, when Mary Gunter eventually achieves conversion we are told that in addition to the "private prayers that she daily read in her Ladies bed chamber, she was thrice every day on her knees before God in secret, like a true worshipper." These communal female practices may again be seen as a creation of gendered time, as well as establishing a gendered space for devotion. Both 
communal and private female reading practices are figured as vital to the "true life of piety" to which Mary Gunter converts.

Group female devotion extended beyond prayer in this household; Lady Dudley additionally "constrained [Mary] to be countable for the sermons which shee heard in the house, which were constantly two every Sabboth day," leading eventually to Mary's demonstrating her "great abilitie to communicate to others the substance of those Sermons which she heard, the rather because it was constantly observed by all the women in that honourable Familie, to come together after the last Sermon, and make repetition of both." ${ }^{31}$ Mary Gunter's submission to these reformist strategies of communal female reading and prayer leads, according to the sermon, to her eventual conversion, aided also by the religious instruction of Lady Dudley's chaplain. As a struggling recusant Mary apparently found, in her earlier life, "much in the Bible which she did not vnderstand." However, through regular recourse to the Bible in the Dudley household, and "earnest Prayer" for understanding, she achieves conversion. The sermon The pilgrim's profession... preached at the funerall of Mrs Mary Gvnter (London, 1622) had been reprinted three times by 1633 and then included in Samuel Clarke's The Lives of Sundry Eminent Persons in this Later Age (1683), proving a very popular narrative and providing an exemplary set of reading practices to enable conversion and the salvation of the soul.

In funeral sermons commemorating a woman, accounts of domestic devotional reading and worship seem never to include men, with the occasional exception of a minister reading sermons in the home. Even then, in the case of Lady Frances Clifton (d. 1628), the mistress of the house is reported to attend the minister's reading with a group of women, not with her husband or any other men. It is notable that this trend of communal female devotion is emphasized and thus endorsed as exemplary in funeral sermons. The eulogy for Clifton, in sketching her daily exercises of devotion, reveals that half of them were performed with other women of the household, even as she prays in bed at night:

Euery morning about fiue of the clocke, she had a light and went to her priuate prayers, lying in her bed. When shee was vp... then oft times some read by her : no sooner dressed, then she and the women went to prayer,... After dinner she was for company, her booke, or exercise, as there was 
occasion. Before Supper againe to Chapel to her God; after Supper and in her bed she \& her women went to praiers. ${ }^{32}$

The portraits of female reading afforded by funeral sermons tell us mostly of how literate women of the higher classes read; there were of course other ways of taking in a text for less educated individuals. Descriptions of communal aural reading, with illiterate "readers" listening to texts being read aloud, do occur in some of these sermons where the deceased in question is praised for undertaking to read like this to her servants or children. Elizabeth Gouge (d. 1626) is one such woman, praised as someone who "did both her selfe diligently and reuerendly attend to the dayly exercises of piety in her house, and cause her children and seruants to the like." ${ }^{33}$ The funeral sermon for Katherine Brettergh likewise mentions that "At the exercises of Religion, as prayer and instruction in her familie, she would not be wanting." 34 "Dayly exercises of piety," I should point out, would have been text-based, consisting of reading the Bible and prayers. Printed manuals of devotion, and printed prayer books, which abound in this period, many designed for or dedicated to women, all stress the confluence of reading and prayer and tend to provide household prayers to read out. Female devotion thus took place along the boundary between oral and print culture: texts that were often heard, like the psalms and sermons, were also read, and these, together with the scriptures, could be read out to other, less literate women by the mistress of the house. Spaces for reading could be both "secret" and communal, on the borders of public and private.

\section{Gendering histories of spiritual struggles on the deathbed}

Funeral sermons containing eulogies are always interested in an account of the individual's last days and moments, since an individual's confrontation with death was regarded as the ultimate trial of her faith. Like the closet, the female deathbed in this exemplary literature is a liminal space, at the boundaries of life and death, of public and private, and of chastity and sexual experience. It is striking that among seventeenth-century funeral sermons, it is usually women who are reported to have struggled with satanic doubt on their deathbed before overcoming these spiritual difficulties. These struggles constitute both the private inner workings of a woman's spiritual life and a drama in which family 
members, and very often the minister who is the author of the sermon, are present as spectators. This boundary between public and private is reflected in the funeral sermon genre itself, in making the details of a private life and death available in print, extending the experience of spectatorship.

The female deathbed often becomes a sexualized space in these sermons, as women are tempted by the wiles of Satan and fight to maintain their spiritual chastity. Mary Gunter is depicted as "molested" by satanic "assaults on her deathbed, which she expected would be "fierce and frequent." This leaves marks of spiritual doubt upon her, and she begins "to question God's loue towards her and the truth of God's grace within her." Satan, "the tempter," is often imagined as a physical presence at a woman's deathbed, and his invasive temptations described in a sexualized language, with an emphasis on molestation and assault. Like Mary Gunter, Anne Rhodes is also described as "grievously assaulted" by Satan upon her deathbed. ${ }^{35}$ Katherine Brettergh is depicted as most vulnerable to satanic assault at the time when she was most physically vulnerable: "Her sicknes tooke her in the manner of a hot burning Ague, which made her... through the tempters subtiltie, which abused the infirmitie of her bodie to that end... to descend into a heauie conflict, with the infirmitie of her owne spirit." At the height of her spiritual doubt, "Sweate burst out vpon her exceedingly, and sometime her bodie burned extreamely." There seems to be an implicit link here between the frailty of the flesh, the fire of the carnal body and the fire of hell. Her biographer comments at this point that "she should have prayed, 'Lead us not into temptation, but was incapable of doing so." ${ }^{36}$ In the account of Mary Gunter's death, God's eventual restraint of Satan is also described in physical terms, as the tempter is finally prevented from resting upon her on her deathbed: when, after six hours Mary Gunter has regained her faith, she offers "cheerful" praises and prayers to God, "for that he had now so chayned Satan at this time of her great weaknes... now he would not suffer him to rest on her with his malice aboue six hours." ${ }^{37}$ The anguish of Satan's metaphorical sexual assualt is the antithesis to the ecstasy of divine love women are shown as enjoying in the closet with Christ, although the liminality of the closet means that, like the deathbed, it can be subject to invasion. Cast in sexual metaphors, the female struggle on the deathbed results from the excessively scrupulous workings of conscience, which Satan seduces so that the dying woman bewails her sinfulness and doubts her salvation. In this respect, these female deathbed narratives also offer a version of gendered time. As Gunter's sermon states, it is "at 
this time of her great weakness" that Satan assaults her, and God subsequently protects her. Dying women are represented as entering into a special time of vulnerable faith (six hours for Gunter), which corresponds to the infirmity of their bodies. The sermon offers exemplary ways in which women can emerge intact from satanic seductions, and thus purify the closing episode of their lives.

In his treatise Conscience with the power and cases thereof, printed in 1639, William Ames writes that while a "tender conscience is easily moved by the word of God," a "troubled Conscience is sometimes honestly good: and sometime sinnefully evil." ${ }^{38}$ A woman, as represented in seventeenth-century funeral sermons, is vulnerable to the "sinnefully evil" function of a too tender conscience. In his Fort for the Afflicted, printed in 1580, John Knox warns in an address to his mother-in-law how a "tender conscience" may be corrupted to become wrongfully troubled:

\begin{abstract}
Sathan wil not cease nowe to perswade to your tender conscience, that none of God his elect hath beene in like case as you are... I remember that ofte you haue complained vpon the grudging and murmuring that you founde, which in your selfe fearing that it prouoked God to more displeasure: Beholde and consider deere mother, what God hath borne with his saintes before: wil hee not beare the same with you, beeing most sorie for your imperfections? ${ }^{39}$
\end{abstract}

Knox apprehends the danger that a feminine "tender conscience" could go too far, which leads to transgression, for as William Perkins pointed out, "euery man be bound in conscience to beleeue his owne Election and saluation by Christ." ${ }^{40}$ With Knox's Fort for the Afflicted, just as in many representations in funeral sermons of women's transitions from doubt to faith on the deathbed, the early modern woman whose "tender conscience" has led her astray is restored to spiritual security through the intervention of a male divine, whose conscience is intact. The preacher of the funeral sermon similarly intervenes in offering advice to readers who might be at risk of a too tender conscience.

Lucinda Becker pertinently remarks that women, the frail sex, needed to "adopt what were considered masculine characteristics in achieving a good death." ${ }^{41}$ A prescription of (masculine) robust responses to satanic assaults on conscience is made in a highly stylized, dramatic narrative of Katherine Stubbes's deathbed struggle with her conscience, inset into her funeral sermon. 
It is presented as a kind of internal monologue supposedly in Stubbes's own language, reporting the suggestions of Satan and supplying answers to his temptations. The artifice of this dialogue, however, draws attention to the exemplarity of the text's function. It is headed "A moste wonderfull conflict betwixt Sathan and her soule, and of her valiant conquest in the same, by the power of Christ." It serves as a catechism, offering female readers the correct answers to satanic assault:

But what doost thou lay to my charge, thy foule fiend? Oh, that I am a sinner, \& therefore shall be damned. I confesse indeed that I am a sinner, and a grievous sinner, both by original sin, and actuall sin, \& that I may thanke thee for. And therefore Sathan I bequeath my sinne to thee from whence it first came, \& I appeale to the mercy of God in Christ Jesus... What more? Sathan, doost thou say that it is written, that God will reward euerie one according to his desarts? So it is written againe (thou deceitfull Deuill) that Christs righteousness is my righteousness, his workes my workes, his merits my merits, and his precious bloud a full satisfaction for all my sinnes. ${ }^{42}$

This account of Katherine Stubbes's "conflict" and "conquest" performs in semidramatic dialogue the role of precise spiritual guidance for the reader served by the scores of other books printed as helps in times of affliction and/or near death in this period, many of them dedicated to women. ${ }^{43}$

Margaret Marwood also suffered an "agony of conscience" on her deathbed, causing her to doubt her salvation,

persisting still in her depairing language, and mournful Elegies, that she was damned, undoubtedly damned; whereupon I asked her what were those inditements that the Devil laid to her charge, what were those sins principally that were her soul-damning sins, that oppressed her conscience, and occasioned her distress. She replyed, She had been a great sinner, for she had used the ordinance of prayer negligently, she had oft been disturbed in duty, by giving a too ready admittance and entertainment to unseasonable, unsuitable thoughts, secular and sinful cogitations, during that holy exercise, and for these, her eyes run down with tears. ${ }^{44}$ 
The excessive workings of Marwood's conscience lead her to doubt her salvation. Yet, Ewbancke is at pains to show us, she manages to read her way back to assurance. The place of female devotional community is also very important in the restoration of Marwood's faith, as we shall see, and it helps to define the gendered space of the deathbed in this sermon. Although Ewbancke seems to have attended Marwood frequently on her deathbed, it is not to him whom she turns for scriptural texts, but rather to her sister. Ewbancke reports that she asked her sister, Lady Wyvel, "whether it was consistent with a Child of God, to doubt so as she did? Whether doubting and believing were consistent?" Lady Wyvel confirms that it is consistent, but Marwood subsequently demands scriptural proof: "you tell me so," she replies, "but doth God tell me so? Shew me where the Scripture saith it." Lady Wyvel shows her sister Luke 22. 31 in which Christ rebukes (but not condemns) Peter (who is after all a believer) with the words "O thou of little faith." Hearing this, Marwood achieves "better satisfaction and quiet of her tender conscience." She assents: "Well, I dare not question the Scriptures; I dare not deny what God affirms; yet my doubts are not quite cured." 45

There follows more sisterly intervention as the community of women around Marwood grows. Ewbancke attempts to intervene "as a spiritual guide and Physitian under God," endeavouring to "prescribe a remedy suitable to her disease." Marwood, interestingly, rejects this patriarchal intercession, refusing to let him pray for her. It is not until her sisters beg to join in prayer for her that she relents, saying, "Well I will see what ye can do, albeit I think you cannot." The sisters gather around the deathbed, alongside Ewbancke who persists in the company of women as steward. As the sisters pray out loud for Marwood, "her countenance began to leap for joy, her sorrow and sighing to fly, and she to give certain signal Testimonies, not only of her zeal in prayer, but also of a present income of the Spirit in answer to prayer." ${ }^{36}$ Ewbancke's representation of the sisterly success in hastening on zeal and spirit in prayer, finally affecting Marwood herself, suggests the minister's deference towards communal female devotion, which often existed in early modern households, and which we see celebrated in funeral sermons. He will not relinquish his role as spiritual custodian, but he does subscribe to a model of female piety that values groups of worshipping women assisting each other with devotional texts. Marwood, in Ewbancke's narrative, expresses her assurance textually. She inhabits, typologically, the voice of Simeon, repeating his words, "Now Lord lettest thou 
thy Servant depart in peace, for mine eyes have seen thy Salvation," and she dies, finally, reciting the beginning of Psalm 116, "I love the Lord, because he hath heard my voice, and my supplications; because he hath inclined his ear unto me; therefore will I call upon him as long as I live." ${ }^{47}$

Ewbancke's sermon makes the exemplary function of the narrative particularly explicit. Marwood's exclamation on the deathbed, "Sister, I thirst for Christ, I hunger for Christ, Oh that the time of my departure were near that I might presently be with Christ," are described by the preacher as "spiritual legacies" for those who heard or read them. Describing Marwood's doubts, resulting from an agony of conscience, Ewbancke warns the readers to see how the Devil plays with small sins to tempt the dying to doubt their salvation. He says: "The use I make of it is this, if thou readest these lines, or hears them read, give a blow to thy conscience in health, thou mayest find it sits heavy upon thy spirit in the time of sickness, these little sins, as probably thou art pleased to term them, which now thou feelest not, may be a trouble to thy conscience and an aking of thy heart on the death-bed." After Marwood has overcome her doubt and spends the rest of her time on the deathbed in pious devotion, Ewbancke makes a special address to any young readers, exclaiming: "O all ye young people, up ye and be doing, heres a Lady hard at work, who is as young as your selves, she dares not take her rest, lest the clock strike, the bell ring, the time (allotted her, for the work) be expired, before the work be finished." ${ }^{48}$

Exemplary death narratives, depicting the struggles and final triumphs of women on the deathbed, encourage women readers of these printed funeral sermons to locate "patterns of virtue" in these accounts as they read. In this way they continue to offer exemplary female histories of reading. The extended title of the funeral sermon for Katherine Stubbes (d. 1590) makes this emphatically clear, in professing to contain a wonderfull combate betwixt Sathan and her soule: worthie to be imprinted in letters of golde, and are to be engrauen in the tables of euery Christian heart. ${ }^{49}$ Indeed, it is sometimes the reading practices of the dying women themselves that are figured as salvational. Like the wealth of godly manuals (many dedicated to women) on preparing for death, these narratives work to equip women with the right reading practices in times of mortal fear. It is often the most pious of women who upon their deathbeds are depicted in violent throes of doubt, which are nonetheless overcome at the last moment, meaning that these women attain an exalted and exemplary faith in surviving satanic assaults. 
Funeral sermons give advice on how to survive these assaults. We saw that Katherine Brettergh read her Bible eight times per day, yet while dying would sometimes "cast her Bible from her, and say: It was indeede the booke of life, but she had read the same vnprofitably, and therefore feared it was become to her the booke of death." We are told that while "the sorrowes of death hemmed [Katherine Brettergh] in and the griefes of hell laid hold vpon her" she "cried out oftentimes, Woe, woe, woe, [I am] a weake, a wofull, a forsaken woman," and that "after a great conflict with Satan she said: 'Satan reason not with me, I am but a weake woman, if thou have any thing to say, say it to my Christ." Towards her death, Brettergh began to be "troubled in conscience" as "the enemy had then begun to assault her." Her friends and local clergymen visited, offering spiritual comfort to assuage her "despaire," yet when she was left alone again, after their departure, "the enemy did more strongly \& strangely assault her againe." As Katherine is brought increasingly back to the word of God through her friends and ministers reading to her, helping her to read, and sometimes sing psalms, we are reassured that "It was the worke of God in her, to suffer Satan to accuse her, and afflict her for her sinnes, that so she might the better see them, and consider the haynousnes of them, and before her departure repent of them, and betake her wholy to Christ for the sauing of her soule." ${ }^{50}$ She achieves, finally, a "good death," having found spiritual comfort and joy in the promises of the scriptures once more, and is thus purified. ${ }^{51}$

Women (reading the funeral sermons) are urged then, either implicitly or explicitly, to read for "patterns of virtue" inhering in the deathbed narratives and representations of devotional practices in the closet and bedchamber. Both the deathbed and the closet are treated as key spaces for the private practice and public performance of female spirituality. These spaces are also associated with experiences of gendered time, such as the childbirth anniversary celebrated in the closet by Lady Clifton; the regular communal female devotional rituals in which Mary Gunter was invited to participate in her mistress's bedchamber; and the special time of vulnerable faith and ultimate spiritual triumph that is experienced on the deathbed.

The deathbed was a final trial of faith, both deeply personal and publicly observed, as the preacher and relatives gathered around the deathbed to allay doubts and to witness the dying woman singing and praying in her journey to Christ. The female closet was also both a public and private space, enclosing the body and existing within the patriarchal domain, yet it might afford secret, 
unknowable mystical union with Christ, as well as other hidden pleasures. In these spaces, women were expected to receive Christ, their spouse, through devotional reading, meditation, and prayer, while rejecting temptations. In the closet these temptations are associated with the pleasures of the flesh, and on the deathbed with satanic seductions into spiritual doubt. In addition to representing the duality of these aspects of women's religious lives, at once public and private, these funeral sermons offer an ambivalent account of female religious agency. These writings carefully attend to female practices in the closet and voices on the deathbed, producing a gendered transition from life to death (and the afterlife), and yet these practices and voices are constructed as exemplary in line with masculine expectations. As a result of this, the spaces associated with female spirituality are sexualized, and the struggles within them become objectified.

In this way, the funeral sermons celebrate a limited female religious agency that is paradoxically associated with confinement. They offer strategies for eschewing temptations of the flesh, and for achieving exemplary devotional practice in spite of the spiritual temptations that are connected to the weakness of the body. The commemorations of godly reading women stress that reading is itself an exemplary act, a suggestion which acts as a silent justification for the printing and selling of the funeral sermon itself. The word is emphasized as the central resource for salvation: Katherine Brettergh overcame her doubts on the deathbed through hearing and reading the scriptures once more, and the printed funeral sermon itself implicitly issues the command Augustine heard: "take up and read."

\section{Notes}

1. Hannibal Gamon, The Praise of a Godly Woman. A sermon preached at the solemne funerall of the right honourable ladie, the Ladie Frances Roberts, at Lanhiderock-Church in Cornwall, the tenth of August, 1626 (London, 1627), pp. 28-29.

2. See Erica Longfellow, "Public, Private, and the Household in Early SeventeenthCentury England," Journal of British Studies 45 (2006), pp. 313-34.

3. Peter Samwaies, The Wise and Faithful Steward. Or, a Narration of the Exemplary Death of Mr Beniamin Rhodes... Together with some Remarkable Passages concer- 
ning Mrs Anne Rhodes his wife, who dying few houres after him, was buried together in the same grave with him (London, 1657), pp. 12-13, 63.

4. Stephen Zwicker, "Habits of Reading and Early Modern Literary Culture," in The Cambridge History of English Early Modern Literature, ed. David Loewenstein and Janel Mueller (Cambridge: Cambridge University Press, 2002), p. 182.

5. Ralph Houlbrooke, Death, Religion and the Family in England 1480-1750 (Oxford: Clarendon Press, 1998), p. 298.

6. Patrick Collinson has associated funeral sermons with a Puritan interest in spiritual life-writing, and while in many cases there is clearly a connection to be made here, it is important to note that funeral sermons were not an exclusively Puritan genre, but were written and published also by preachers such as John Donne, Richard Hooker, and William Fuller. Fuller was the author of a funeral sermon for Lady Frances Clifton, which I will discuss in this essay, and was accused of being a "Popish innovator" by his parish. It is not necessarily the funeral sermon genre itself that signals religious identity, but rather how the genre was used.

7. The sermons preached at the funeral of Katherine Brettergh in 1602 were reprinted four times between 1601 and 1617. Lancelot Langhorne's sermon on Mary Swain in 1611 also went into four editions (1624-33). A sermon for Elizabeth Juxon was reprinted in three editions (1620-22), while that for her husband, Stephen Denison, was not reprinted. See Jeri Lynne McIntosh, "English Funeral Sermons 1560-1640: The Relationship Between Gender and Death, Dying, and the Afterlife" (Ph.D. diss., University of Oxford, 1990), p. 57.

8. McIntosh, pp. 58-63.

9. George Ewbancke, The Pilgrims Port or the Weary Man's Rest in the Grave Opened And improved in a Sermon, at the Funeral of the Honourable Ms. Margeret Marwood, Wife to Hen. Marwood Esq; Together with a Character of the deceased Gentlewoman; briefly describing the Tenure of her Life, and maner of her Death (London, 1660), sig. A9 ${ }^{\text {r }}$

10. Ewbancke, p. 127.

11. Alice Friedman, House and Household: Woollaton Hall and the Willoughby Family (London: University of Chicago Press, 1989), p. 8.

12. Richard Rambuss, Closet Devotions (Durham and London: Duke University Press, 1998), p. 107.

13. Kevin Sharpe and Steven N. Zwicker, eds., Reading, Society, and Politics in Early Modern England (Cambridge: Cambridge University Press, 2003), p. 15. 
14. Lena Cowen Orlin discusses nine different functions of early modern female closets in “Gertrude's Closet," Shakespeare Jahrbuch 134 (1998), pp. 44-67.

15. Katherine R. Larson, Early Modern Women in Conversation (Basingstoke: Palgrave Macmillan, 2011), pp. 39-59.

16. Edward Taylore, Mary Magdalens love to Christ. Opened in a sermon preached at the funeral of Mistris Elizabeth Thomason (London: 1659), p. 66.

17. Richard Brathwaite, The English Gentlewoman (London, 1631), p. 44.

18. "The holie life and Christian death of Mistris Katherin Brettergh... With the manner of a bitter conflict she had with Satan, and blessed conquest by Christ, before her death, to the great glorie of God, and comfort of all beholders," in William Harrison and William Leygh, Deaths Advantage Little Regarded, and the soules solace against sorrow. Preached... at the burial of Mistris Katherin Brettergh the third of Iune. 1601... Whereunto is annexed, the Christian life and godly death of the said Gentlewoman (London, 1602), p. 2.

19. Brathwaite, p. 43.

20. Sasha Roberts has explored male fear and disapproval in early modern England surrounding women's closets as possible spaces for reading erotic texts, during a period when a poem such as Shakespeare's Venus and Adonis made popular reading for both men and women. See "Shakespeare 'creepes into the womens closets about bedtime': Women Reading in a Room of Their Own," in Renaissance Configurations: Voices/Bodies/Spaces, 1580-1690, ed. Gordon McMullan (Basingstoke: Palgrave Macmillan, 1998) pp. 30-63.

21. Alan Stewart, “The Early Modern Closet Discovered," Representations 50 (1995), pp. 76-100 (p. 87).

22. Georgianna Ziegler, "My Lady's Chamber: Female Space, Female Chastity in Shakespeare," Textual Practice 4 (1990), p. 76. Larson, however, in Early Modern Women in Conversation, has recently challenged the idea that bounded spaces could be equated with the silence of early modern women, despite these conventions (pp. 39-59).

23. “The holie life and Christian death of Mistris Katherin Brettergh," p. 8. This latter part of the work has been attributed to William Hinde: see Deaths advantage little regarded... a facsimile reproduction with an introduction by Retha $M$. Warnicke and Bettie Anne Doebler (Delmar, New York: Scholars Facsimiles and Reprints, 1993), p. 12. 
24. Thomas Brooks, A String of Pearls: or, the best things reserved till last... a sermon preached at the Funeral of (that triumphant saint) Mris. Mary Blake, late Wife to... $\mathrm{Mr}$ Nicholas Blake, Merchant, with an Elegy on her Death (London, 1657), sig. C1 ${ }^{\mathrm{v}}$.

25. The concept of mystical marriage, using language from the Song of Solomon, appears not only in male-authored exemplary literature such as funeral sermons, but also, as Erica Longfellow and Elizabeth Clarke have explored, in female religious literature, in which women setting forth their devotional life in language figured themselves as the Bride of Christ. See Longfellow, Women and Religious Writing in Early Modern England (Cambridge: Cambridge University Press, 2004); Elizabeth Clarke, Politics, Religion and the Song of Songs in Seventeenth-Century England: Rewriting the Bride (Basingstoke: Palgrave Macmillan, 2011).

26. The Bible that is the Holy Scriptures conteined in the Olde and Newe Testament translated according to the Ebrewe and Greeke, and conferred with the best translations in diuers languages; with most profitable annotations vpon all the harde places... (London, 1576), p. 163.

27. Daniel Featley, Ancilla Pietatis: or, the Handmaid to Private Devotion (1626), sig. A $6^{r}$.

28. William Fuller, The Mourning of Mount Libanon: Or, the Temples Teares. A Sermon Preached... In Commemoration of the Right Honourable and Religious Lady, the Lady Frances Clifton (London, 1628), p. 28.

29. See, for instance, The Diary of Lady Margaret Hoby 1599-1605, ed. Dorothy Meads (London, Routledge, 1930); Grace Mildmay, Autobiographical and spiritual reflections, Northamptonshire Central Library: Northamptonshire Studies Collection (1570-1617); and Elizabeth Isham, My Book of Rememberance, Princeton University Library, Robert H. Taylor Collection, MS RTCO1 (c. 1639). For more on Margaret Hoby's communal reading see Mary Ellen Lamb, “The Sociality of Margaret Hoby's Reading Practices," Critical Survey 12 (2000), pp. 17-32. Micheline White has explored literary dimensions of female religious communities in "Women Writers and Literary-Religious Circles in the Elizabethan West Country: Anne Dowriche, Anne Lock Prowse, Anne Lock Moyle, Ursula Fulford, and Elizabeth Rous," Modern Philology 103 (2005), pp. 187-214.

30. Humphrey Gunter, "A Profitable Memoriall of the Conversion, Life, and Death of $\mathrm{M}^{\mathrm{ris}}$ Mary Gvnter, set vp as a Monument, to be looked vpon both by Protestants and Papists," in The Pilgrims Profession (London, 1625), pp. 131-32.

31. Gunter, pp. 133-34.

32. Fuller, p. 31. 
33. Guy Nichols, Pietie's Pillar; or, A sermon preached at the funerall of mistresse Elizabeth Gouge... (London, 1626), pp. 47-48.

34. "The holie life and Christian death of Mistris Katherin Brettergh," pp. 8-9.

35. Samwaies, p. 7.

36. “The holie life and Christian death of Mistris Katherin Brettergh," pp. 11, 13.

37. Thomas Taylor, The Pilgrims Profession (London, 1625), pp. 184-85.

38. William Ames, Conscience with the power and cases thereof (London, 1639), p. 44.

39. John Knox, A Fort for the Afflicted Wherin are Ministred many Notable \& Excellent Remedies Against the Stormes of Tribulation... (London, 1580), sig. A5 ${ }^{\mathrm{r}}$.

40. William Perkins, A Discourse of Conscience: Wherein is set downe the nature, properties, and differences thereof... (Cambridge, 1596), p. 29.

41. Lucinda Becker, Death and the Early Modern Englishwoman (Aldershot: Ashgate, 2003), p. 44.

42. Philip Stubbes, A christal glass for Christen women, containing, a most excellent discourse, of the godly life and Christian death of Mistresse Katherine Stubs... (London, 1592), sig. C3 .

43. Some examples include Thomas Barnes, Needfull helpes: against desperate perplexitie (London, 1624); Nicholas Byfield, The cure of the fear of death (London, 1618); William Cowper, Two fruitfull and godly treatises, to comfort the afflicted (London, 1616); William Fulke, A comfortable sermon of faith, in temptations and afflictions (London, 1574); Adam Harsnet, A cordiall for the afflicted: touching the necessitie of afflictions (London, 1632); William Perkins, A salue for a sicke man, or, the right manner of dying well (London, 1595); Richard Smyth, Munition against mans misery and mortality (London, 1612); and John Trapp, Gods love-tokens, and the afflicted mans lessons (London, 1637). All of the above books have female dedicatees.

44. Ewbancke, pp. 144-45.

45. Ewbancke, pp. 167-71.

46. Ewbancke, p.151.

47. Ewbancke, p. 177.

48. Ewbancke, pp. 148, 158.

49. Philip Stubbes, above.

50. "The holie life and Christian death of Mistris Katherine Brettergh," pp. 12, 15, 21.

51. Houlbrooke, pp. 183-219. 
